\title{
Financial Structure and Macroeconomic Volatility: A Panel Data Analysis
}

\author{
Emiel F. S. van Bezooijen ${ }^{1} \&$ Jacob A. Bikker ${ }^{2}$ \\ ${ }^{1}$ Utrecht School of Economics (USE), Utrecht University, Utrecht, The Netherlands \\ ${ }^{2}$ De Nederlandsche Bank (DNB), Amsterdam, The Netherlands, and USE \\ Correspondence: Jacob A. Bikker, Economic Policy \& Research Division, DNB, P.O. Box 98, 1000 AB \\ Amsterdam, the Netherlands. Tel: 31-6-3027-2997. E-mail: j.a.bikker@dnb.nl
}

Received: October 28, 2019

Accepted: November 27, 2019

Online Published: November 30, 2019

doi:10.5539/ijef.v11n12p117

URL: https://doi.org/10.5539/ijef.v11n12p117

\begin{abstract}
In 2015, the European Commission (EC) launched its action plan for the creation of a European Capital Markets Union. The EC aims to return the European economy to sustainable growth and to enhance its shock-absorbing capacity by reducing the reliance on bank finance and stimulating financial deepening and cross-border integration of Europe's capital markets. Financial diversification and integrated European capital markets are expected to improve risk sharing among households, supporting economic stability. However, the economic literature reveals a lack of theoretical and empirical consensus on the superiority of either a bank-based or a market-based financial system in promoting growth or reducing macroeconomic volatility. This article is the first to include bond markets in its financial structure indicators, besides stock markets and bank lending. Using panel data on 55 countries between 1975 and 2014 and three different measures of financial structure, we investigate the effect of the structure of the financial system on the volatility of output and investment growth as well as their cyclical components. We do not find evidence that market-based financial structures dampen volatility of output or overall investment. Increase of the stock market size relative to that of the banking sector has a significant positive effect on the business cycle volatility of investments.
\end{abstract}

Keywords: financial development, financial system structure, macroeconomic volatility, market-based finance, bank-based finance, capital market integration, business cycle

\section{Introduction}

In September 2015, the European Commission (EC) launched its action plan for the creation of a European Capital Markets Union (CMU). This flagship initiative of the Juncker Commission aims at creating a single European capital market for all EU member states (EC, 2015). Since the 1990s, the European banking sector has grown significantly larger (relative to GDP) than those of other jurisdictions, particularly the United States (see Figure 1) (Note 1). This has made the financial structures of the majority of European countries strongly bank-based, with bank lending playing a significantly larger role in corporate sector funding than market issuance of debt and equity securities (Langfield \& Pagano, 2016). In addition, corporate bond and equity market capitalisation in the EU is relatively underdeveloped compared to other jurisdictions (see Figures 2 and 3 ).

The introduction of the CMU aims at stimulating the financial deepening and cross-border integration of domestic capital markets and removing the obstacles encountered by European businesses when attracting funds on capital markets, complementing banks as a source of financing (EC, 2015). The EC asserts that the CMU will ensure greater diversification in the funding of the economy and reduce the cost of raising capital, particularly for small and medium-sized enterprises (SMEs). It should also enhance the flow of capital from investors to European investment projects, improving allocation of risk and capital across the EU (EC, 2015). Moreover, financial diversification and integrated European capital markets should improve risk sharing among households, contributing to lower volatility of income and consumption and supporting economic stability (Anderson et al., 2015). The CMU would also make Europe more resilient to shocks to the economy by enhancing its shock-absorbing capacity (EC, 2015). Besides the envisaged effects for macroeconomic and financial stability, the EC believes that although banks will continue to play a vital role in the European economy a move to a more market-oriented European financial system is necessary in order to support a sustainable return to economic growth and job creation (EC, 2015). 


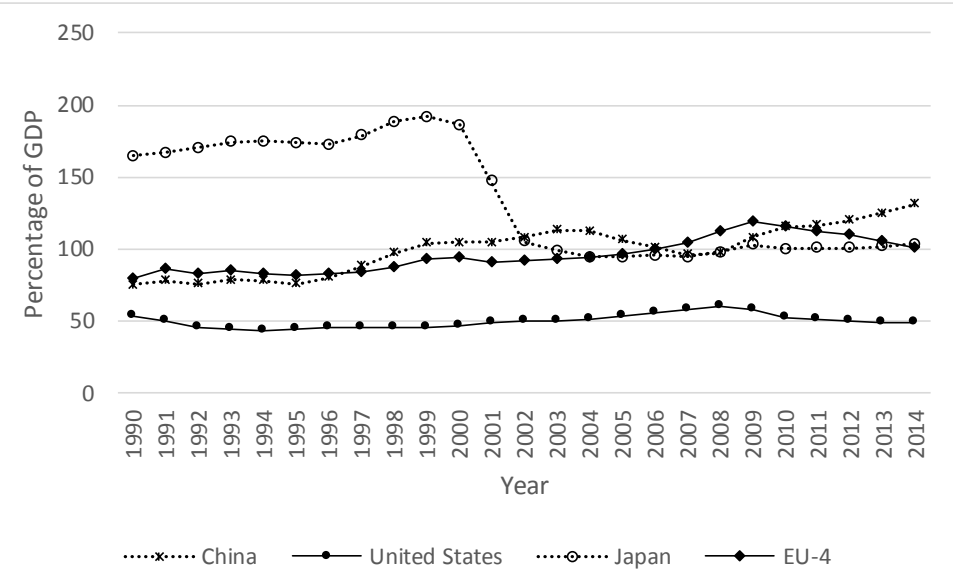

Figure 1. Credit to the private sector by deposit money banks (percentage of GDP)

Source: World Bank, Financial Structure Database (September 2019).

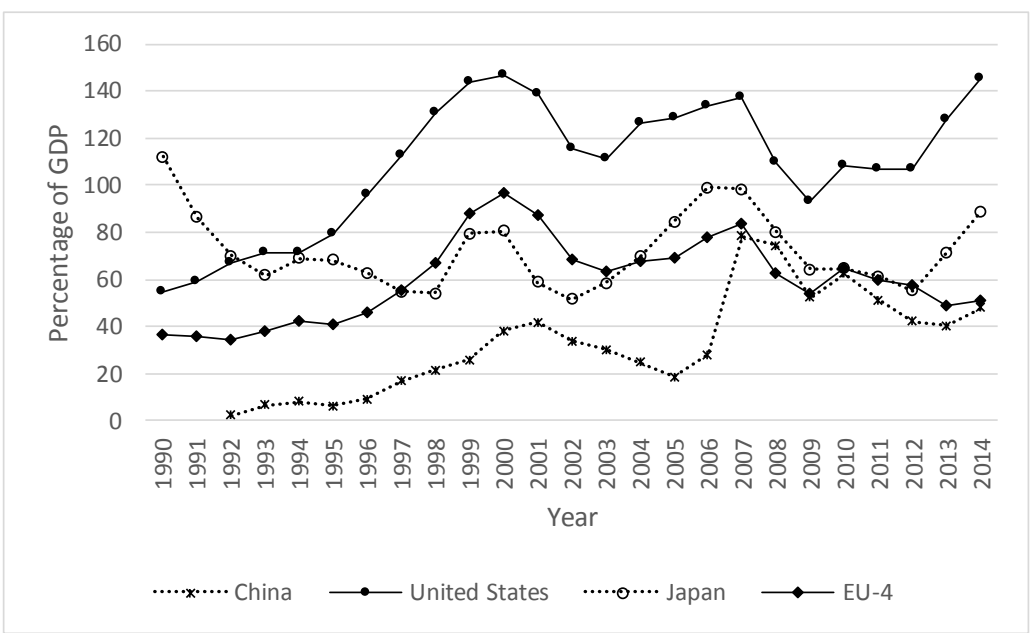

Figure 2. Stock market capitalization (percentage of GDP)

Source: World Bank, Financial Structure Database (September 2019).

The relative dominance of bank financing in the European financial system and the underdevelopment of European financial markets relative to those in the US may be a key factor explaining the difference in economic recovery in both areas after the financial crisis of 2007-2009. Since the crisis, EU growth has been lagging behind that of the US, which recovered faster from the worldwide economic meltdown (see Figure 4). The financial crisis impaired bank's lending abilities in both areas but the effect on the real economy in the EU exceeded that of the US, due to the heavy reliance on bank financing (Financial Times, November 2015). In a market-oriented financial system, participants in the financial system may be better able to substitute bank credit with market financing following a credit crunch, thus dampening the effect on the real economy (Bijlsma et al., 2015). Crouzet (2014) finds that asymmetric shocks to bank's lending costs, such as the 2007-2009 financial crisis, have a larger effect if an economy is initially bank-dependent, such as is the case in the majority economies in the Eurozone. In addition, European banks initially put off the necessary balance sheet restructuring and instead rolled over credit in order to postpone loss recognition, essentially turning into 'zombie banks' (Caballero, 2008). In contrast, their US counterparts were able to restructure much quicker, backed by the troubled asset relief program (Tarp), paving the way for a sustainable recovery (Financial Times, November 9, 2015).

Despite the difference in recovery between the market-oriented US and the relatively bank-oriented EU, there is no consistent empirical evidence available on the superiority of market-based financial systems in promoting growth and stability (Bijlsma et al., 2015). Although several studies have investigated the impact of the structure 
of the financial system on economic growth, there seems to be neither empirical nor theoretical consensus on the superiority of bank-based or market-based financial systems. In addition, despite the importance of macroeconomic stability for foster growth (Ramey \& Ramey, 1995) and income equality (Breen \& García-Peñalosa, 2005), literature that examines the relationship between financial structure and macroeconomic volatility is scarce and has primarily relied on financial structure indicators based on the relative size and activity of the stock markets to that of banks and does not include corporate bond markets.

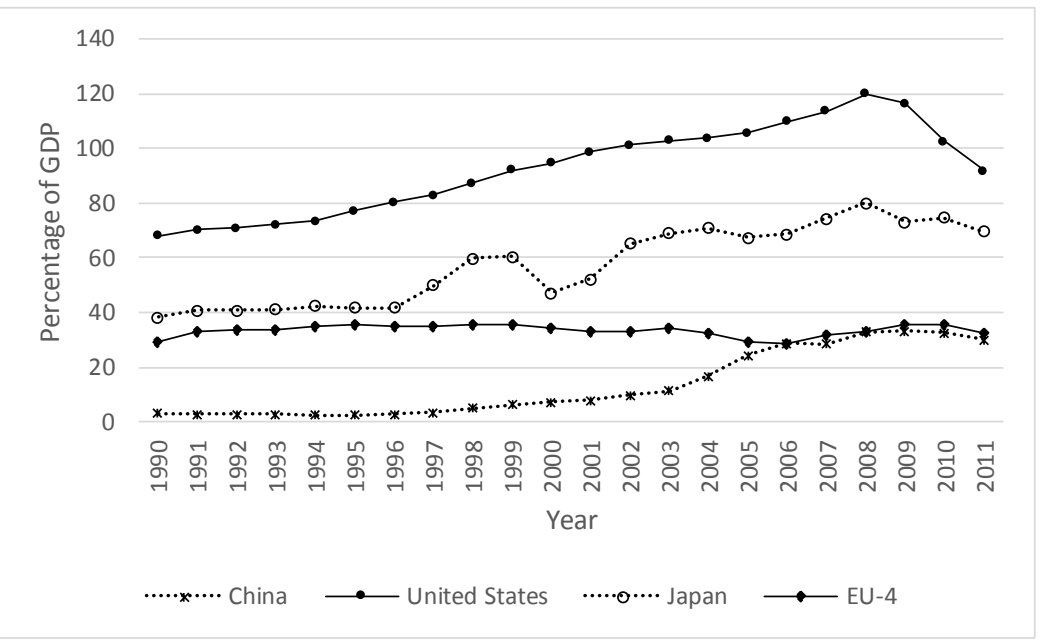

Figure 3. Private bond market capitalization (percentage GDP)

Source: World Bank, Financial Structure Database (September 2019).

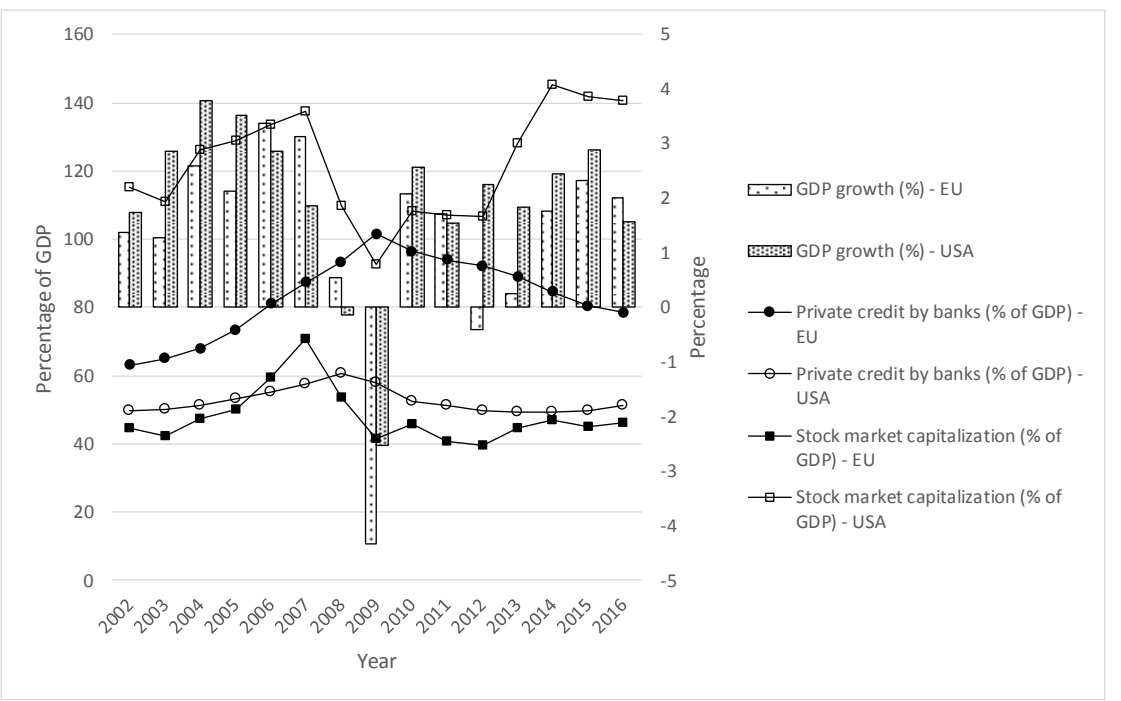

Figure 4. United States and EU GDP growth, banking sector and stock market size

Source: World Bank, World Development Indicators.

We add to the small body of empirical studies in the structure-volatility nexus by investigating the effect of financial system structure on macroeconomic volatility. In addition, this study contributes to the existing body of literature by incorporating corporate bond market capitalisation into one of our financial structure indicators in order to create a more comprehensive measure of financial system structure. Using panel data of 55 countries between 1975 and 2014 and three alternative measures of financial system structure, we investigate the effect of financial structure on both the overall and the cyclical volatility of output and investment growth. The panel results show that more market-oriented financial structures are not associated with lower overall and business cycle volatility of output or overall investment growth volatility. Remarkably enough, we observe that an increase in the stock market size relative to that of the banking sector has a significant positive effect on business 
cycle volatility of investment growth.

Section 2 of our article provides a review of the literature and Section 3 describes the data and methodology. Section 4 discusses the main empirical results for output growth and Section 5 does the same for investment growth. Section 6 presents our conclusions and Section 7 discusses the limitations of the present article and offers suggestions for future research.

\section{Literature Review}

\subsection{Financial Intermediaries Development and Macroeconomic Volatility}

Financial development refers to the depth and sophistication of a financial system (Phumiwasana, 2003). Financial development occurs when the entire financial system - consisting of capital markets and financial intermediaries - improves in its ability to ameliorate the effects of information, enforcement, and transactions costs and can better provide its functions (Levine, 2005). The link between financial development and macroeconomic volatility is rooted in the external financing needs of financially constrained firms, whose borrowing capacity is influenced by the existence of financial market imperfections (Wei \& Kong, 2016). Shocks to the real economy are propagated and amplified through a 'financial accelerator' that operates through the credit channel and arises due to information asymmetries between lenders and borrowers in the credit markets (Bernanke et al., 1999; Gertler \& Bernanke, 1995). According to the 'balance sheet view', a negative shock that causes a fall in firms' net worth increases agency cost by worsening the potential conflict between lenders and borrowers. This leads to a higher external finance premium, which magnifies the fluctuations in borrowing, spending and investment and therefore in real economic activity (Gertler \& Bernanke, 1995; Kiyotaki \& Moore, 1997). Similarly, the external financing premium is positively related to the dependency of borrowers on external financing. A shock that reduces a firm's current cash flow reduces the firm's ability to finance from retained earnings, increasing its dependency on external finance and, consequently, the external finance premium (Wei \& Kong, 2016). Due to the pro-cyclical nature of cash flows and the net worth of businesses, the external finance premium is countercyclical (external finance premium is lower, the higher the net worth of businesses is). An initial shock exogenous to the real economy is amplified by the existence of financial frictions, such as adverse selection and moral hazard problems, resulting in larger business cycle fluctuations (Dabla-Norris \& Srivisal, 2013). In addition, an initial shock to the financial sector could affect the real economy by limiting the amount of funds that can be channelled from lenders to borrowers. This credit tightening causes borrowers to reduce their spending and hiring, which causes real economic activity to decline (Quadrini, 2011).

Well-developed financial intermediaries can help mitigate the effect of financial frictions, associated with asymmetric information problems, on macroeconomic volatility by lowering the cost of acquiring and verifying information. Banks develop expertise in acquiring information and can mobilise economies of scale in terms of screening and monitoring borrowers. This reduces both adverse selection and post-lending moral hazard problems. The associated fall in financial frictions will curb the financial accelerator effect and smoothen the business cycle (Da Silva, 2002). Aghion et al. (2000) argue that countries with poorly developed financial systems tend to be more volatile, as the demand for and supply of credit tends to be more cyclical. They find that deeper financial systems can reduce the volatility of investment and growth by alleviating liquidity constraints on firms and facilitate long-term investment. In addition, financial intermediaries could stabilise macroeconomic fluctuations by allowing better risk management. Acemoglu and Zilibotti (1997) find that the presence of indivisible projects limits the risk diversification of an economy. The inability to diversify idiosyncratic risk and the presence of risk-averse agents in the financial markets hamper the accumulation of capital and introduce uncertainty in the growth process. They argue that the development of financial intermediaries can facilitate greater risk diversification and thereby dampen economic growth fluctuations.

A large body of empirical studies has examined the link between financial intermediary development and macroeconomic volatility. Denizer et al. (2002) find that financial sector development is associated with lower volatility in output, consumption and investment growth. They also find that banks play a particularly important role in reducing volatility in consumption and investment growth, suggesting that banks provide risk management and information processing services that are particularly important for consumption smoothing and reducing investment volatility. Similar results are presented by Da Silva (2002) who finds that financial system development, particularly that of the banking sector, is associated with lower volatility in the business cycle components of output, investment and consumption.

However, other studies have found a non-linear relationship between financial intermediary development and macroeconomic stability. Dabla-Norris and Srivisal (2013) find that financial sector depth reduces overall and business cycle volatility of output, consumption, and investment growth, but only up to a certain point. Once 
financial development exceeds this point, further deepening could amplify consumption and investment volatility. Similarly, Easterly et al. (2001) find a similar U-shaped relationship between financial sector development and growth volatility using panel data for 60 countries. Alatrash et al. (2014) also find a U-shaped relationship between financial sector size and GDP growth volatility in countries with high a quality financial sector. The non-linear relationship could potentially be explained by increased risk-taking by agents in countries with a well-developed financial sector and higher firm leverage (Alatrash et al., 2014; Easterly et al., 2001).

Other studies have shown that the effect of financial sector development can differ in terms of its impact on cyclical- and overall macroeconomic volatility. Wei and Kong (2016) find that financial intermediary development reduces short-term output volatility but has no significant effect on trend volatility of GDP. Mallick (2014) observes that financial intermediary development only affects business-cycle volatility and has no significant impact on the overall volatility of GDP growth. He finds that private credit dampens business-cycle volatility, particularly for middle-income countries, but has no effect on overall volatility of output.

The volatility of an economy is inevitably related to shocks and how an economy is able to absorb these shocks (Easterly et al., 2000). Several studies have shown that the effect of financial intermediary development on macroeconomic volatility is not unambiguous and depends on the kind of shock that a country faces. Dabla-Norris and Srivisal (2013) find that deeper financial sectors might serve as shock-absorbers mitigating the effect of external shocks on macroeconomic volatility. Bacchetta and Caminal (2000) argue that financial sector development could dampen the effects of productivity shocks on macroeconomic volatility. Beck et al. (2006) find that well-developed financial intermediaries can dampen the effect of real sector shocks by alleviating agency costs and cash-flow constraints. However, the impact of monetary shocks may be magnified in countries where businesses have limited access to capital markets as an alternative source of external funding while no effect is found in countries with well-developed stock markets.

\subsection{Capital Market Development and Macroeconomic Volatility}

Although studies that examine the relationship between financial development and macroeconomic volatility are abundant, the majority of them have relied on proxies of financial development that capture the development of financial intermediaries relative to the size of the economy. However, these proxies only measure how well financial intermediaries function in terms of financing investment or spending of both businesses and households (Tharavanij, 2007). The financial development indicators used in the majority of these studies only measure the development of the 'indirect financing channel' and do not capture the development of capital markets that may have an independent effect on economic growth and volatility. Development of capital markets as part of the overall financial system reduces financial frictions by improving disclosure and higher transparency in the financial system, reducing asymmetrical information and agency costs (Tharavanij, 2007). Furthermore, deep and liquid capital markets lower liquidity risk and enhance access to finance and investments through bond and equity issuance (Levine, 2005). In addition, capital markets offer diversification opportunities which would reduce idiosyncratic risk (Tharavanij, 2007).

Tharavanij (2007) illustrates the importance of incorporating measures of direct finance, even after controlling for the level of financial intermediation. He finds that countries with more developed capital markets have less volatile investment and output growth. Sahay et al. (2015) argue that the non-linear relationship between financial intermediation development and macroeconomic stability arises due to increasing financial stability risk. However, they also assert that this result does not hold for capital market development, which is found to reduce macroeconomic volatility. In contrast, Wei and Kong (2016), using data for 30 regions in China, find that financial market development has no significant effect on macroeconomic volatility. Mallick (2014) finds that stock market capitalisation reduces business-cycle volatility, but only in low-income countries.

\subsection{Financial Structure and Macroeconomic Volatility}

Another relevant line of research has examined the relationship between the structure of a country's financial system and its economic performance. Whereas financial development refers to the size and activity of the financial system as a whole, financial structure refers to the infrastructure of finance providers and their relative importance in the provision of financial services in the economy (Phumiwasana, 2003; World Bank, 2013). Ideally, a measure of financial structure would encompass the size and activity of the entire financial system. However, the most common classification in the literature distinguishes between market-based or bank-based financial systems.

A vast body of literature has examined the relationship between the structure of a financial system and economic growth. This literature focuses on the relative merits of bank-based and market-based financing in providing services that induce economic growth (for an overview, see Allen \& Gale, 2001; Levine, 2005). However, there 
is no theoretical consensus on the superiority of either system and some studies have disregarded the fruitfulness of the distinction between the two financial structures altogether. These studies suggest that it is the overall financial development that enhances long-term growth (Beck et al., 2001; Levine, 2002; Levine \& Zervos, 1998). Proponents of the bank-based view have argued that banks diminish adverse selection problems through the ex-ante screening of borrowers, and reduce moral hazard by monitoring firms' ex-post investment decisions by specialising in obtaining and processing information. The free-riders problem inherent in security markets may disincentivize individual market participants to engage in similar costly information-based activities. In addition, banks may be better at facilitating intertemporal smoothening of non-diversifiable risk (Allen \& Gale, 1997). Proponents of the market-based view have argued that markets allow for better diversification of risk and have questioned the superiority of banks in reducing moral hazard problems. They have argued that there is a time-inconsistency in the threat of cutting credit in the face of default, which makes the threat improbable. Security markets are more credible due to the high renegotiation costs associated with renegotiating with many bond holders (Allen \& Gale, 2001).

The importance of a country's financial structure could also be assessed to the degree that banks and markets enable efficient risk sharing and reducing financial frictions. As argued earlier, reducing financial frictions and risks inherent in the financial system enhances the resilience of the economy to macroeconomic shocks, with implications which beneficially affects macroeconomic stability. However, as in the structure-growth nexus, there is no clear theoretical consensus on the superiority of either system's stabilising effects. Both banks and markets allow channelling of funds from those with a surplus to those in need of financing. However, real and monetary shocks could be transmitted differently through the intermediated and non-intermediated channel. In response to a shock to the economy, banks are more likely to internalise short-term adjustment costs, due to relative rigidity of lending and savings rates. In a deep and liquid capital markets, shocks have a more immediate effect on asset prices as the market adjusts and moves to a new equilibrium. Following this line of reasoning, banks can soften the immediate impact of a shock by absorbing the shock onto their balance sheets rather than immediately transmitting them to consumers in the short-run. However, banks can also contribute to fluctuations in economic activity by tightening credit and shifting to safer assets.

Due to the counter-cyclical nature of credit standards and the consequential procyclical nature of credit provision, banks can fuel a boom during upturns by expanding their credit provision and aggravate contraction during downturns by reducing it. Financial market participants may exhibit similar behaviour, but may exacerbate volatility even further by displaying herding behaviour. However, the presence of risk-seeking investors in the financial markets could reduce fluctuations in economic activity. These investors are willing to bear more risk for potentially higher returns, and will continue to provide funds during downturns. This in turn will alleviate the financial constraints that businesses have. During economic downturns, banks may be reluctant to write off or sell their assets at a loss, which would immediately impact their profits. Holding a large proportion of non-performing loans could impair the banking sector's ability to provide new credit, increasing financial constraints for businesses and contributing to a further slowdown (Phumiwasana, 2007).

On the subject of systemic risk, some have argued that the lack of transparency and limited disclosure in relationship banking (a common feature of bank-based financial systems) could lead to a collapse of credit provision in the event of a bank run (Rajan \& Zingales, 2001). If one intermediary fails, healthy intermediaries may be unable to step in due to the firm-specific knowledge inherent in bank-firm relationships. In addition, depositors may be unable to distinguish between healthy and unhealthy banks, adding to contagion risk in the financial system. Fecht (2004) develops a theoretical model and shows that contagion risk is particularly high in moderately bank-based financial systems. When capital markets lack depth and liquidity, fire sales of a distressed bank's assets could cause asset prices to drop and impede the balance sheets of other intermediaries.

Finally, an issue that is closely related to the present study is the spare-tire concept, which refers to the idea that having a well-diversified financial system can have a stabilising effect on the economy. In a well-diversified financial system, banks and markets may act as substitutes if one finance channel gets clogged. According to this argument, development of capital markets would reduce macroeconomic volatility more than a bank-based financial system would do alone. Fiore and Uhlig (2015) find that when a financial crisis impairs the banking sector's flexibility in the provision of credit, the scope for businesses to shift from bank to market financing can dampen the adverse real effect of a credit crunch by alleviating the credit constraints that businesses face. However, during normal times when banks can provide ample flexibility, substitutability of external financing sources has a less prominent effect on aggregate economic activity. Levine et al. (2016) find evidence that the ability of firms to substitute bank by capital market financing during a systemic banking crisis ameliorate the effects of the crisis on profits, employment and investment efficiency. Although this finding is consistent with 
the spare-tire view, Levine et al. (2016) find that financial intermediary and stock market development prior to the crisis have no significant effect on external finance substitutability. However, the services provided by banks and markets differ and may not be perfect substitutes (Phumiwasana, 2007). In addition, development of markets could impede the ability of the financial system to allow for intertemporal smoothing of risk, which could have a destabilising effect on the economy. When banks face competition from the market, individuals with excess funds may move to the capital market during an economic upturn, hampering the accumulation of reserves that could act as a buffer during a downturn (Allen \& Gale, 1997).

The relatively scarce body of empirical literature in the structure-volatility nexus has not provided consistent evidence on the impact of financial structure on economic stability. Tharavanij (2007) finds that countries with relatively market-oriented financial systems exhibit lower output and investment growth volatility. Although he does not find a significant effect of the relative degree of market orientation on business cycle volatility, the signs are consistently negative. Yeh et al. (2013) find that market-based countries experience faster growth, but this is at the cost of greater macroeconomic fluctuations in the long run. A possible explanation for the positive relationship between market-oriented financial systems and macroeconomic volatility could be that banks - as coordinated coalitions of investors - have a comparative advantage over uncoordinated markets at reducing post-lending moral hazard, owing to superior monitoring activities. Stock markets can create disincentives for rigorous corporate control since investors can inexpensively sell their shares. Arguably, in more market-oriented financial systems, corporate performance may be monitored less stringently. This in turn can cause more unpredicted outcomes in production and thus increased volatility in economic growth (Boot \& Thakor, 1997). Da Silva (2002) and Denizer et al. (2000) find no significant relationship between financial structure and business-cycle volatility. Phumiwasana (2003) finds that bank-based financial systems increase volatility among developed countries, but are associated with lower growth volatility in developing countries. Wei and Kong (2016) show that the measure of financial structure used, matters when examining its effect on macroeconomic volatility. They find that a higher ratio of the turnover rate to financial development efficiency enhances both cyclical and trended volatility. However, when financial structure was measured by stock market capitalisation and financial development efficiency, higher degrees of market orientation did not have a significant impact on trended volatility, but were found to reduce cyclical volatility.

Other studies have examined the link between financial structure and output volatility at the industry level. For example, Raddatz (2006) examines the link between financial development and volatility at the industry level. $\mathrm{He}$ finds that financial intermediaries are more important than equity markets for reducing industry-level output volatility. As previously mentioned, financial development and macroeconomic volatility are linked through the existence of financial frictions which amplify shocks by financially constrained firms. Baum et al. (2011) examine how obstacles to external financing may vary across financial systems. They find that both the financial development and the financial structure of a country are important determinants of the financial constraints that firms face. They show that bank-based systems are more successful in alleviating financial constraints.

Some articles have examined the relationship between a country's financial structure and the probability and intensity of an economic downturn. Easterly et al. (2000) observe that financial sector depth is associated with a higher probability of a downturn, while stock market depth reduces the likelihood of a downturn, possibly due to better risk diversification opportunities. These findings suggest that economies that rely more heavily on debt-finance are more vulnerable to economic downturns. Gambacorta et al. (2014) find that economies with bank-oriented financial systems are more resilient during 'normal' downturns. Banks can draw on long-term relationships with their customers and are therefore more willing to continue extending credit during a downturn. However, market-oriented systems are found to be more resilient during a financial crisis when the banking sector's shockrabsorbing capacity is impaired. Langfield and Pagano (2016) examine this effect of financial structure in European countries on their stability and growth. They find that an increase in the banking sector relative to equity and private bond markets is associated with more systemic risk and hence lower stability.

\section{Data and Methodology}

We use annual data of 55 countries between 1975 and 2014 (see Table A.1 in the appendix). This number of countries provides us with a larger dataset, but at the cost of a higher level of heterogeneity. The annual data are transformed into eight sub-periods, each covering a five-year time span (Note 2). For all variables except volatility, the annual data is transformed into five-year averages. Volatility measures are transformed by calculating the standard deviations within the respective five-year periods. Missing data points are replaced by averaging the available data points for a given time-span, under the condition that at least three data points are present for a given five-year period. If this condition is not met, the particular five-year observation in the panel is treated as missing. Tables A.2-4 in the appendix give an overview of the included variables, their sources, 
descriptive statistics and the correlation matrix.

We explain macroeconomic volatility by financial structure and financial development using a reduced-form equation:

$$
\sigma_{i t}=\beta_{0}+\beta_{1} F S_{i t}+\beta_{2} F D_{i t}+\beta_{3} X_{i t}+\varepsilon_{i t}
$$

The dependent variable, $\sigma$, measures volatility defined as the natural logarithm of the standard deviation of either output growth (based on real GDP per capita) or investment growth (based on gross fixed capital formation). Volatility of real GDP per capita growth is frequently used in the literature as a measure of macroeconomic volatility (e.g. Alatrash et al., 2014; Dabla-Norris \& Srivisal, 2013; Mallick, 2014; Tharavanij, 2007; Klomp \& De Haan, 2009) In addition to this measure of growth cycles volatility, this article also extracts the cyclical components from output and investment growth in order to measure business cycle volatility of GDP and investment growth. Cyclical variations are separated from the trend using the Christiano-Fitzgerald band-pass filter technique, which extracts cyclical fluctuations that last two to eight years.

FS and FD in Equation (1) are indicators of financial structure and financial system development, respectively. In order to capture the effect of financial structure on macroeconomic volatility, we use three different measures of financial structure. The first measure is 'structure-activity', which measures the activity of the stock market relative to that of banks. More specifically, following Levine (2002) it is defined as the ratio of total value traded to bank credit (Note 3). This measure captures stock market activity relative to banking sector activity. The second measure of financial structure is 'structure-size', which - in line with Levine (2002) - is defined as the ratio of domestic stock market capitalisation to total bank credit. The third measure is 'structure-size (incl. bonds)', which is similar to the second measure, but it includes capitalisation of the private bond market in the numerator. This numerator is a more comprehensive indicator of the domestic capital market size, as it captures both the size of the domestic stock market and that of the domestic private bond market. Higher values of these three structure measures indicate a higher level of market orientation.

For financial system development, we also use three different measures. 'Finance-activity' is a measure of the activity of stock markets and intermediaries and is defined as the sum of total value traded and private credit (Note 4). The second measure for financial system development is 'finance-size', which captures the size of stock markets and financial intermediaries and is defined as the sum of stock market capitalisation and private credit. In order to develop a more comprehensive measure of financial system depth, we use finance-size including private bond market capitalisation as an alternative measure of financial system development. Both the financial development and the financial structure indicators enter the regression in natural logarithmic form (Note 5).

$\mathrm{X}_{\mathrm{it}}$ denotes a set of control variables which may also affect macroeconomic volatility. Some studies have shown that developing countries tend to experience much more growth volatility than developed countries do (e.g. Easterly \& Stiglitz, 2000). To control for the economy size, we include the natural logarithm of GDP per capita. Governments can influence a country's economy through fiscal policy measures, so the fiscal policy stance may affect macroeconomic fluctuations. In order to take account of this, we include the ratio of government consumption expenditure to GDP. Several studies have established an impact of both financial and trade openness on macroeconomic volatility (e.g. Kose, 2009). The sum of foreign direct investment inflows and outflows (both in absolute terms) relative to GDP is used as a proxy for financial openness. Trade openness is proxied by the ratio of the sum of imports and exports to GDP. Both the financial openness and trade openness indicators enter the regression in natural logarithmic form. The standard deviation of changes in real effective exchange rates is included to control for the effect of exchange rate volatility on macroeconomic volatility. Exchange rate volatility may influence domestic production and consumption decisions, particularly in open economies. However, the impact of both exchange rate volatility and openness on volatility are theoretically ambiguous: fewer trade barriers may increase exposure to shocks from abroad, but can also allow shocks to the domestic economy to be 'exported' and thus reduce macroeconomic volatility. In addition, the effect of exchange rate flexibility on business cycle volatility may differ, depending on the origin of a shock (Da Silva, 2002; Tiryaki, 2003; Tharavanij, 2007). We also include terms of trade volatility as a proxy for external shocks, the Polity Index, which captures the characteristics of a country's political regime, and inflation rates.

In order to account for potential endogeneity of the explanatory variables of Equation (1), which is indeed a reduced form model, we conduct instrumental variable (IV) estimations. More specifically, the financial development and structure indicators are instrumented by their first (five-year) lagged values. We performed a Wu-Hausman test to test whether the financial development and structure indicators are endogenous, but we also have theoretical arguments to expect endogeneity. In addition to applying instrumental variables in pooled OLS, 
we perform fixed effect estimations (IVFE) to check the robustness of our findings.

\section{Estimation Results of Output Growth Volatility Models}

Table 1 shows the regression outcomes of the output growth volatility model. As measures of financial development and structure we apply, respectively, 'finance-activity' and 'structure-activity' (model 1), 'finance-size' and 'structure-size', both based on stock market capitalisation only (model 2), and finance-size and structure-size indicators, both based also on the private bond market (model 3). The Wu-Hausman test statistic is insignificant for all three models, suggesting that all financial structure and financial development measures can be treated as exogenous. For theoretical reasons, however, we apply instrumental variables throughout. The F-test statistic on the fixed effects in the IVFE estimations is insignificant in all three models' estimations, so that the null hypothesis of absence of country-specific effects cannot be rejected. Hence, we consider the IV estimations as the appropriate ones and will not discuss the IVFE estimates in detail.

The financial structure indicator is found to have an insignificant effect on output growth volatility. Hence, moving towards a more market-oriented financial system does not significantly reduce GDP growth volatility, based on this approach. Our finding contradicts that of Tharavanij (2007) (Note 6), who observes a significant negative effect of financial structure on output growth volatility. In contrast, Yeh et al. (2013) find a significant positive effect. Our insignificant result is similar to that of Phumiwasana (2003).

Finance-activity and the bonds included finance-size indicator of financial development have a significant negative effect on output growth volatility. These outcomes suggest that enhancing the activity in the financial system may be beneficial in terms of fostering output growth stability. This finding is similar to that of Tharavanij (2007) who observes a negative impact of both financial-market and financial-sector activity on macroeconomic growth volatility. The impact of the stock-based finance-size indicator (Model 2) is insignificant. In contrast, Wei and Kong (2016) show that an increase in the stock market size has a negative effect on output growth, while any effect of financial intermediary development is insignificant. Similarly, Mallick (2014) find no significant effect of financial intermediary development.

The (IVFE) outcomes in Table 1 show that our findings regarding the effect of financial structure on output growth volatility are consistent, even after controlling for country-fixed effects. But the effect of the finance-activity and the bond included finance-size indicator of financial development lose their significance in the IVFE estimations. This also holds for trade openness, terms of trade volatility, GDP per capita, inflation and the polity index. Note that fixed effects estimates ignore information in the explanatory variables, which are constant per country, so that only changes over time are used, which apparently provide less information than cross-country differences. As an additional robustness check, we apply weighted regression with GDP per capita in order to assign higher weights to countries with more economic development. The previously reported outcomes are robust under this alternative estimation approach.

Table 2 shows the regression outcomes of the business-cycle volatility of GDP growth model. As measures of financial development and structure we apply, respectively 'finance-activity' and 'structure-activity' (model 1) and 'finance-size' and 'structure-size', both based on stock market capitalisation only (model 2), and finance-size and structure-size indicators, both based also on private bond market capitalisation (model 3). The Wu-Hausman test statistic is insignificant for all three models, suggesting that all financial structure and financial development measures can be treated as exogenous. However, as above, we apply instrumental variable estimation throughout for theoretical reasons. The F-test statistic on the fixed effects in the IVFE estimations is insignificant in all three model estimations, indicating that country-specific effects have no significant impact on business cycle volatility of output growth. Hence, we again consider the IV estimations as the correct ones.

As is the case for total output growth volatility, the financial structure indicator has a consistent insignificant effect on business cycle volatility of output growth. So based on this approach, a higher degree of market-orientation in the financial system does not reduce cyclical fluctuations in output growth. This outcome is consistent with those of Tharavanij (2007), Wei and Kong (2016) and Da Silva (2002).

The finance-activity (model 1) and the stock-based finance-size (model 2) indicators of financial development have a significant negative effect on business cycle volatility of output growth, while the bonds included size indicator (model 3) is insignificant. This indicates that expansion of the activity as well as the size of the financial system may result in reduction of business cycle volatility of output growth. These results are consistent with those of Wei and Kong (2016) and Mallick (2014). In contrast, Tharavanij (2007) observes a negative effect of stock market turnover (used as an absolute measure of stock market development) on cyclical output volatility, but observes no effect of financial intermediary development. The outcomes indicate that finance-activity has a significant negative effect on both overall and business cycle volatility of output growth, 
whereas the stock-based size structure indicator only impacts business cycle volatility of output growth and the bonds included size indicator only has a significant negative effect on overall output growth volatility.

Table 1. Growth volatility model estimates (1975-2014)

\begin{tabular}{|c|c|c|c|c|c|c|}
\hline & \multicolumn{2}{|c|}{ Model 1} & \multicolumn{2}{|c|}{ Model 2} & \multicolumn{2}{|c|}{ Model 3} \\
\hline & IV & IVFE & IV & IVFE & IV & IVFE \\
\hline Finance-activity & $\begin{array}{c}-0.307 * * \\
(-2.22)\end{array}$ & $\begin{array}{l}-1.298 \\
(-1.18)\end{array}$ & & & & \\
\hline Structure-activity & $\begin{array}{l}0.036 \\
(0.85)\end{array}$ & $\begin{array}{l}-0.108 \\
(-0.59)\end{array}$ & & & & \\
\hline Finance-size & & & $\begin{array}{l}-0.209 \\
(-1.38)\end{array}$ & $\begin{array}{l}-1.090 \\
(-1.07)\end{array}$ & & \\
\hline Structure-size & & & $\begin{array}{c}0.0436 \\
(0.43)\end{array}$ & $\begin{array}{l}-0.086 \\
(-0.35)\end{array}$ & & \\
\hline Finance-size (incl. bonds) & & & & & $\begin{array}{l}-0.265^{*} \\
(-1.67)\end{array}$ & $\begin{array}{l}11.19 \\
(0.45)\end{array}$ \\
\hline Structure-size (incl. bonds) & & & & & $\begin{array}{l}0.127 \\
(0.83)\end{array}$ & $\begin{array}{l}-0.248 \\
(-0.05)\end{array}$ \\
\hline Financial openness & $\begin{array}{l}0.012 \\
(0.18)\end{array}$ & $\begin{array}{l}0.395 \\
(1.43)\end{array}$ & $\begin{array}{l}-0.005 \\
(-0.07)\end{array}$ & $\begin{array}{l}0.245 \\
(1.35)\end{array}$ & $\begin{array}{l}0.051 \\
(0.46)\end{array}$ & $\begin{array}{l}0.181 \\
(0.17)\end{array}$ \\
\hline Trade openness & $\begin{array}{c}0.235^{*} \\
(1.94)\end{array}$ & $\begin{array}{l}0.606 \\
(0.95)\end{array}$ & $\begin{array}{c}0.285^{* *} * \\
(2.47)\end{array}$ & $\begin{array}{l}0.549 \\
(0.92)\end{array}$ & $\begin{array}{c}0.351 * * \\
(2.55)\end{array}$ & $\begin{array}{l}3.487 \\
(0.56)\end{array}$ \\
\hline GDP per capita (US\$) & $\begin{array}{c}0.178 * * \\
(2.49)\end{array}$ & $\begin{array}{l}0.730 \\
(0.88)\end{array}$ & $\begin{array}{c}0.165^{* * *} \\
(2.16)\end{array}$ & $\begin{array}{l}0.630 \\
(0.88)\end{array}$ & $\begin{array}{c}0.176^{*} \\
(1.89)\end{array}$ & $\begin{array}{l}-7.985 \\
(-0.52)\end{array}$ \\
\hline Terms of trade volatility & $\begin{array}{c}1.889^{*} \\
(1.74)\end{array}$ & $\begin{array}{c}3.663 * \\
(1.79)\end{array}$ & $\begin{array}{c}2.262^{*} \\
(1.88)\end{array}$ & $\begin{array}{l}3.618 \\
(1.59)\end{array}$ & $\begin{array}{l}2.515 \\
(0.99)\end{array}$ & $\begin{array}{l}-13.57 \\
(-0.27)\end{array}$ \\
\hline Exchange rate volatility & $\begin{array}{l}-0.717 \\
(-0.69)\end{array}$ & $\begin{array}{l}-2.296 \\
(-1.28)\end{array}$ & $\begin{array}{l}-0.645 \\
(-0.56)\end{array}$ & $\begin{array}{l}-0.765 \\
(-0.45)\end{array}$ & $\begin{array}{l}-2.530 \\
(-1.04)\end{array}$ & $\begin{array}{l}-12.99 \\
(-0.81)\end{array}$ \\
\hline Government consumption & $\begin{array}{l}-0.005 \\
(-0.43)\end{array}$ & $\begin{array}{l}0.007 \\
(0.16)\end{array}$ & $\begin{array}{l}-0.003 \\
(-0.20)\end{array}$ & $\begin{array}{l}0.005 \\
(0.08)\end{array}$ & $\begin{array}{l}-0.000 \\
(-0.00)\end{array}$ & $\begin{array}{l}-0.802 \\
(-0.39)\end{array}$ \\
\hline Inflation & $\begin{array}{c}0.001^{* * * *} \\
(4.10)\end{array}$ & $\begin{array}{c}0.0016 \\
(0.50)\end{array}$ & $\begin{array}{l}0.005 \\
(0.66)\end{array}$ & $\begin{array}{l}-0.005 \\
(-0.29)\end{array}$ & $\begin{array}{c}0.057 * * * \\
(3.57)\end{array}$ & $\begin{array}{l}0.436 \\
(0.59)\end{array}$ \\
\hline Polity & $\begin{array}{c}-0.0264 * * \\
(-2.45)\end{array}$ & $\begin{array}{l}-0.059 \\
(-1.51)\end{array}$ & $\begin{array}{c}-0.021 * * \\
(-2.08)\end{array}$ & $\begin{array}{l}-0.013 \\
(-0.30)\end{array}$ & $\begin{array}{c}-0.0214 \\
(-1.49)\end{array}$ & $\begin{array}{l}1.162 \\
(0.32)\end{array}$ \\
\hline Constant & $\begin{array}{c}-5.013 * * * \\
(-7.40)\end{array}$ & $\begin{array}{l}-8.275 \\
(-1.44)\end{array}$ & $\begin{array}{c}-5.638 * * * \\
(-7.63)\end{array}$ & $\begin{array}{c}-7.670^{*} \\
(-1.71)\end{array}$ & $\begin{array}{c}-5.929 * * * \\
(-5.46)\end{array}$ & $\begin{array}{l}7.014 \\
(0.23)\end{array}$ \\
\hline Number of observations & 187 & 187 & 180 & 180 & 84 & 84 \\
\hline R-squared & 0.147 & & 0.143 & & 0.250 & \\
\hline Number of country FE & & 53 & & 53 & & 34 \\
\hline Wu-Hausman test & 1.714 & & 1.610 & & 1.729 & \\
\hline Prob $>$ F & $0.00^{* * * *}$ & $0.00 * * *$ & $0.00^{* * *}$ & $0.00 * * *$ & $0.00 * *$ & $0.00 * * *$ \\
\hline Prob $>F_{u}$ & & 0.991 & & 0.956 & & 1.00 \\
\hline $\operatorname{Corr}\left(\mathrm{u}_{\mathrm{i}}, \mathrm{X}_{\mathrm{b}}\right)$ & & -0.913 & & -0.854 & & -0.985 \\
\hline
\end{tabular}

Note. Robust z-statistic in parenthesis. * significant at $10 \%$, ** significant at $5 \%$, *** significant at $1 \%$; IV means instrumental variable estimation (instruments: first lagged value of financial development and financial structure variables), IVFE is short of fixed effects instrumental estimation (instruments: first lagged value of financial Trade openness has a consistent and significant positive effect on output growth volatility in all three IV estimations, in line with Easterly et al. (2000), but contradicts the observations of Tharavanij (2007), Dabla-Norris and Srivisal (2013) and Mallick (2014). Terms of trade volatility has a significant positive effect on output growth volatility in two out of three IV estimations, like the observations of Mallick (2014) and Easterly et al. (2000), but contradictory to those of Tharavanij (2007). Interestingly, GDP per capita has a significant positive effect in all three IV estimations, suggesting that output volatility is higher in more developed countries. Inflation has a significant positive effect in two IV estimations. The measure of political regime, polity, is significantly negative in two models. This suggests that countries with more democratic political regimes are more stable in terms of output growth volatility. Similarly, Klomp and De Haan (2009) find that more democracy is associated with lower volatility in output growth. Finally, the effect of government consumption, financial openness and exchange rate volatility is found to be insignificant. development and financial structure variables), Wu-Hausman tests on exogeneity of instrumented variables, Prob > F tests on joint significance of all explanatory variables except constant, Prob $>F_{u}$ tests on joint significance of all cross-country individual effects, Corr $\left(X_{b}, u_{i}\right)$ means correlation of the predicted value of the dependent variable $\left(\mathrm{X}_{\mathrm{b}}\right)$ and individual fixed effects $\left(\mathrm{u}_{\mathrm{i}}\right)$. 
Table 2. Business cycle volatility of output model estimates (1975-2014)

\begin{tabular}{|c|c|c|c|c|c|c|}
\hline & \multicolumn{2}{|c|}{ Model 1} & \multicolumn{2}{|c|}{ Model 2} & \multicolumn{2}{|c|}{ Model 3} \\
\hline & IV & IVFE & IV & IVFE & IV & IVFE \\
\hline \multirow[t]{2}{*}{ Finance-activity } & $-0.325^{* * *}$ & -1.202 & & & & \\
\hline & $(-2.63)$ & $(-1.29)$ & & & & \\
\hline \multirow[t]{2}{*}{ Structure-activity } & 0.0394 & -0.145 & & & & \\
\hline & $(0.81)$ & $(-0.95)$ & & & & \\
\hline \multirow[t]{2}{*}{ Finance-size } & & & $-0.252 * *$ & -1.233 & & \\
\hline & & & $(-2.05)$ & $(-1.44)$ & & \\
\hline \multirow[t]{2}{*}{ Structure-size } & & & 0.064 & -0.095 & & \\
\hline & & & $(0.68)$ & $(-0.47)$ & & \\
\hline \multirow[t]{2}{*}{ Finance-size (incl. bonds) } & & & & & -0.170 & 10.660 \\
\hline & & & & & $(-1.23)$ & $(0.46)$ \\
\hline \multirow[t]{2}{*}{ Structure-size (incl. bonds) } & & & & & 0.170 & -0.927 \\
\hline & & & & & $(1.30)$ & $(-0.20)$ \\
\hline \multirow[t]{2}{*}{ Financial openness } & -0.013 & 0.333 & -0.030 & 0.226 & -0.003 & 0.255 \\
\hline & $(-0.20)$ & $(1.43)$ & $(-0.46)$ & $(1.49)$ & $(-0.03)$ & $(0.25)$ \\
\hline \multirow[t]{2}{*}{ Trade openness } & $0.230^{*}$ & 0.791 & $0.281 * * *$ & 0.802 & $0.349 * * *$ & 2.834 \\
\hline & $(1.93)$ & (1.47) & $(2.63)$ & $(1.60)$ & $(3.05)$ & $(0.48)$ \\
\hline \multirow[t]{2}{*}{ GDP per capita (US\$) } & $0.226 * * *$ & 0.638 & $0.210^{* * *}$ & 0.658 & 0.128 & -6.884 \\
\hline & $(3.42)$ & $(0.92)$ & $(2.98)$ & $(1.10)$ & (1.39) & $(-0.48)$ \\
\hline \multirow[t]{2}{*}{ Terms of trade volatility } & 1.510 & 2.293 & $1.958 *$ & 2.689 & 1.644 & -16.300 \\
\hline & $(1.52)$ & $(1.33)$ & $(1.80)$ & $(1.41)$ & $(0.78)$ & $(-0.35)$ \\
\hline \multirow[t]{2}{*}{ Exchange rate volatility } & -0.311 & -2.348 & -0.034 & -1.015 & -0.329 & -10.640 \\
\hline & $(-0.36)$ & $(-1.55)$ & $(-0.04)$ & $(-0.71)$ & $(-0.17)$ & $(-0.71)$ \\
\hline \multirow[t]{2}{*}{ Government consumption } & -0.005 & 0.040 & -0.002 & 0.016 & 0.012 & -0.077 \\
\hline & $(-0.44)$ & $(0.84)$ & $(-0.15)$ & $(0.37)$ & $(0.08)$ & $(-0.18)$ \\
\hline \multirow[t]{2}{*}{ Inflation } & $0.000 * *$ & 0.0001 & 0.001 & -0.010 & $0.041 * * *$ & 0.362 \\
\hline & $(2.55)$ & $(0.26)$ & $(0.13)$ & $(-0.67)$ & $(3.22)$ & $(0.52)$ \\
\hline \multirow[t]{2}{*}{ Polity } & $-0.032 * * *$ & $-0.056^{*}$ & $-0.026^{* * *}$ & -0.020 & $-0.031 * *$ & 1.114 \\
\hline & $(-2.98)$ & $(-1.71)$ & $(-2.59)$ & $(-0.56)$ & $(-2.16)$ & $(0.33)$ \\
\hline \multirow[t]{2}{*}{ Constant } & $-5.385^{* * *}$ & $-8.701 *$ & $-5.844 * * *$ & $-8.455 * *$ & $-6.044 * * *$ & 1.598 \\
\hline & $(-9.86)$ & $(-1.79)$ & $(-10.21)$ & $(-2.25)$ & $(-6.83)$ & $(0.06)$ \\
\hline Number of observations & 187 & 187 & 180 & 180 & 84 & 84 \\
\hline R-squared & 0.183 & & 0.177 & & 0.245 & \\
\hline Number of country FE & & 53 & & 53 & & 35 \\
\hline Wu-Hausman test & 1.758 & & 1.628 & & 0.139 & \\
\hline Prob $>F$ & $0.00^{* * * *}$ & $0.00^{* * *}$ & $0.00 * * *$ & $0.00^{* * *}$ & $0.00^{* * * *}$ & $0.00 * * *$ \\
\hline Prob $>F_{u}$ & & 0.803 & & 0.490 & & 1.00 \\
\hline $\operatorname{Corr}\left(u_{i}, X_{b}\right)$ & & -0.914 & & -0.880 & & -0.984 \\
\hline
\end{tabular}

Note. Robust z-statistic in parenthesis. * significant at $10 \%, * *$ significant at $5 \%, * * *$ significant at $1 \%$; IV means instrumental variable estimation (instruments: first lagged value of financial development and financial structure variables), IVFE is short of fixed effects instrumental estimation (instruments: first lagged value of financial development and financial structure variables), Wu-Hausman tests on exogeneity of instrumented variables, Prob $>\mathrm{F}$ tests on joint significance of all explanatory variables except constant, Prob $>F_{u}$ tests on joint significance of all cross-country individual effects, Corr $\left(\mathrm{X}_{\mathrm{b}}, \mathrm{u}_{\mathrm{i}}\right)$ means correlation of predicted valued of the dependent variable $\left(\mathrm{X}_{\mathrm{b}}\right)$ and individual fixed effects $\left(\mathrm{u}_{\mathrm{i}}\right)$.

Trade openness has a consistent and significant positive effect on business cycle volatility of output growth in IV estimations, in line with Mallick (2014). Tharavanij (2007), however, finds that higher trade openness is associated with lower business cycle volatility of output, while Da Silva (2002) and Wei and Kong (2016) observe no significant effect. These outcomes indicate that countries with more open economies are more vulnerable to external shocks, which may have a positive effect on business cycle volatility of output growth. GDP per capita has a significant positive effect in two out of three estimations. These outcomes suggest that developed countries experience more business cycle fluctuations in output growth. Inflation has a significant positive effect in two out of three estimations. The polity measure has a consistent and significant negative sign across all estimations, telling us that countries with more democratic regimes experience less business cycle fluctuations in output growth.

The fixed effect estimations (IVFE) reported in Table 2 as a robustness check, show that our findings regarding 
the effect of financial structure are consistent after controlling for country-specific effects. However, the finance-activity and stock-based size indicators of financial development, as well as all other control variables, lose their statistical significance when controlling for country-specific effects. It confirms that FE estimates are less appropriate. A second robustness test is weighing regressions with weights based on GDP per capita, which provides very similar results.

\section{Estimation Results of the Investment Growth Volatility Models}

Table 3 shows the regression outcomes of the investment growth volatility model. As measures of financial development and structure we use, respectively 'finance-activity' and 'structure-activity' (model 1), 'finance-size' and 'structure-size', both based on stock market capitalisation only (model 2), and finance-size and structure-size indicators based also on the private bond market (model 3). The Wu-Hausman test statistic is significant in all three models, so that the null hypothesis of exogeneity is rejected and the financial development and structure measures should be treated as endogenous. We apply instrumental variables throughout (Note 7).

Table 3. Investment growth volatility model estimates (1975-2014)

\begin{tabular}{|c|c|c|c|c|c|c|}
\hline & \multicolumn{2}{|c|}{ Model 1} & \multicolumn{2}{|c|}{ Model 2} & \multicolumn{2}{|c|}{ Model 3} \\
\hline & IV & IVFE & IV & IVFE & IV & IVFE \\
\hline Finance-activitity & $\begin{array}{c}-0.269 * * \\
(-2.53)\end{array}$ & $\begin{array}{l}-1.280 \\
(-1.36)\end{array}$ & & & & \\
\hline Structure-activity & $\begin{array}{l}-0.011 \\
(-0.27)\end{array}$ & $\begin{array}{l}-0.369 \\
(-1.63)\end{array}$ & & & & \\
\hline Finance-size & & & $\begin{array}{c}-0.191^{*} \\
(-1.69)\end{array}$ & $\begin{array}{c}-2.71 \\
(-1.31)\end{array}$ & & \\
\hline Structure-size & & & $\begin{array}{l}0.072 \\
(0.78)\end{array}$ & $\begin{array}{l}-0.398 \\
(-0.84)\end{array}$ & & \\
\hline Finance-size (incl. bonds) & & & & & $\begin{array}{l}-0.313^{*} \\
(-1.90)\end{array}$ & $\begin{array}{r}16.460 \\
(0.45)\end{array}$ \\
\hline Structure-size (incl. bonds) & & & & & $\begin{array}{l}0.186 \\
(0.96)\end{array}$ & $\begin{array}{l}0.160 \\
(0.03)\end{array}$ \\
\hline Financial openness & $\begin{array}{l}-0.040 \\
(-0.60)\end{array}$ & $\begin{array}{l}0.407 \\
(1.58)\end{array}$ & $\begin{array}{l}-0.057 \\
(-0.86)\end{array}$ & $\begin{array}{l}0.466 \\
(1.29)\end{array}$ & $\begin{array}{l}-0.095 \\
(-0.76)\end{array}$ & $\begin{array}{l}-0.381 \\
(-0.24)\end{array}$ \\
\hline Trade openness & $\begin{array}{c}0.442 * * * \\
(4.00)\end{array}$ & $\begin{array}{l}0.381 \\
(0.65)\end{array}$ & $\begin{array}{c}0.554 * * * \\
(4.94)\end{array}$ & $\begin{array}{l}0.825 \\
(0.97)\end{array}$ & $\begin{array}{c}0.745^{* * * *} \\
(4.39)\end{array}$ & $\begin{array}{l}3.148 \\
(0.35)\end{array}$ \\
\hline GDP per capita (US\$) & $\begin{array}{l}-0.042 \\
(-0.73)\end{array}$ & $\begin{array}{l}1.000 \\
(1.25)\end{array}$ & $\begin{array}{c}-0.107^{*} \\
(-1.72)\end{array}$ & $\begin{array}{l}1.725 \\
(1.12)\end{array}$ & $\begin{array}{l}0.025 \\
(0.29)\end{array}$ & $\begin{array}{r}-11.890 \\
(-0.54)\end{array}$ \\
\hline Terms of trade volatility & $\begin{array}{c}2.967 * * * \\
(2.88)\end{array}$ & $\begin{array}{c}4.109 * * \\
(1.97)\end{array}$ & $\begin{array}{c}3.229 * * * \\
(3.36)\end{array}$ & $\begin{array}{l}6.608 * \\
(1.74)\end{array}$ & $\begin{array}{c}5.112 * * \\
(2.41)\end{array}$ & $\begin{array}{l}-20.560 \\
(-0.29)\end{array}$ \\
\hline Exchange rate volatility & $\begin{array}{l}-0.139 \\
(-0.14)\end{array}$ & $\begin{array}{l}-1.019 \\
(-0.59)\end{array}$ & $\begin{array}{l}-1.140 \\
(-1.27)\end{array}$ & $\begin{array}{l}1.767 \\
(0.57)\end{array}$ & $\begin{array}{l}-1.594 \\
(-0.52)\end{array}$ & $\begin{array}{l}-10.200 \\
(-0.44)\end{array}$ \\
\hline Government consumption & $\begin{array}{c}-0.0144 \\
(-1.16)\end{array}$ & $\begin{array}{l}0.001 \\
(0.03)\end{array}$ & $\begin{array}{l}-0.007 \\
(-0.58)\end{array}$ & $\begin{array}{l}-0.044 \\
(-0.49)\end{array}$ & $\begin{array}{l}0.017 \\
(0.89)\end{array}$ & $\begin{array}{l}-0.931 \\
(-0.31)\end{array}$ \\
\hline Inflation & $\begin{array}{c}0.001 * * * \\
(3.89)\end{array}$ & $\begin{array}{l}0.000 \\
(0.38)\end{array}$ & $\begin{array}{c}0.018 * * \\
(2.14)\end{array}$ & $\begin{array}{l}-0.032 \\
(-0.84)\end{array}$ & $\begin{array}{c}0.049 * * \\
(2.01)\end{array}$ & $\begin{array}{l}0.586 \\
(0.55)\end{array}$ \\
\hline Polity & $\begin{array}{c}0.025 * * * \\
(2.61)\end{array}$ & $\begin{array}{l}-0.048 \\
(-1.17)\end{array}$ & $\begin{array}{c}0.037 * * * \\
(3.67)\end{array}$ & $\begin{array}{l}-0.019 \\
(-0.29)\end{array}$ & $\begin{array}{l}-0.008 \\
(-0.43)\end{array}$ & $\begin{array}{l}2.004 \\
(0.38)\end{array}$ \\
\hline Constant & $\begin{array}{c}-2.812^{* * *} \\
(-4.18)\end{array}$ & $\begin{array}{l}-8.988 \\
(-1.56)\end{array}$ & $\begin{array}{c}-3.162 * * * \\
(-4.61)\end{array}$ & $\begin{array}{l}-9.871 \\
(-1.19)\end{array}$ & $\begin{array}{c}-4.887 * * * \\
(-4.18)\end{array}$ & $\begin{array}{l}17.290 \\
(0.40)\end{array}$ \\
\hline Number of observations & 178 & 178 & 170 & 170 & 84 & 84 \\
\hline R-squared & 0.310 & & 0.327 & & 0.275 & \\
\hline Number of country FE & & 52 & & 52 & & 34 \\
\hline Wu-Hausman test & $3.915^{* *}$ & & $8.437 * * *$ & & $5.393 * * *$ & \\
\hline Prob $>$ F & $0.00^{* * *}$ & $0.00^{* * * *}$ & $0.00 * * *$ & $0.00^{* * * *}$ & $0.00 * *$ & $0.00 * * *$ \\
\hline Prob $>F_{u}$ & & 0.828 & & 0.998 & & 1.000 \\
\hline $\operatorname{Corr}\left(\mathrm{u}_{\mathrm{i}}, \mathrm{X}_{\mathrm{b}}\right)$ & & -0.887 & & -0.934 & & -0.984 \\
\hline
\end{tabular}

Note. Robust z-statistic in parenthesis. * significant at $10 \%, * *$ significant at $5 \%$, *** significant at 1\%; IV means instrumental variable estimation (instruments: first lagged value of financial development and financial structure variables), IVFE is short of fixed effects instrumental estimation (instruments: first lagged value of financial development and financial structure variables), Wu-Hausman tests on exogeneity of instrumented variables, Prob $>\mathrm{F}$ tests on joint significance of all explanatory variables except constant, Prob $>F_{u}$ tests on joint significance of all cross-country individual effects, Corr $\left(\mathrm{X}_{\mathrm{b}}, \mathrm{u}_{\mathrm{i}}\right)$ means correlation of predicted valued of the dependent variable $\left(\mathrm{X}_{\mathrm{b}}\right)$ and individual fixed effects $\left(\mathrm{u}_{\mathrm{i}}\right)$. 
Similar to the overall and business cycle volatility output growth volatility model's estimations, the financial structure indicator in all three models has an insignificant effect on investment growth volatility. This finding is inconsistent with that of Tharavanij (2007), who observes a significant negative effect of financial structure on investment growth volatility. All three financial development indicators have a significant negative effect. This finding suggest that an increase in activity in the financial system as well as an explanation of the financial system size may result in reduced investment growth fluctuations, similar to our findings in the output growth models. Trade openness, terms of trade volatility and inflation have consistent significant positive effects. The polity index has a significant negative effect in two IV estimations. These outcomes are in line with expectations. The other explanatory variables do not exhibit consistent or significant effects on investment growth volatility (Note 8).

Table 4. Business cycle volatility of investment growth model estimates (1975-2014)

\begin{tabular}{|c|c|c|c|c|c|c|}
\hline & \multicolumn{2}{|c|}{ Model 1} & \multicolumn{2}{|c|}{ Model 2} & \multicolumn{2}{|c|}{ Model 3} \\
\hline & IV & IVFE & IV & IVFE & IV & IVFE \\
\hline Finance-activity & $\begin{array}{c}-0.363 * * * \\
(-3.15)\end{array}$ & $\begin{array}{l}-0.983 \\
(-1.34)\end{array}$ & & & & \\
\hline Structure-activity & $\begin{array}{c}0.0401 \\
(0.84)\end{array}$ & $\begin{array}{l}-0.170 \\
(-0.97)\end{array}$ & & & & \\
\hline Finance-size & & & $\begin{array}{c}-0.318 * * * \\
(-2.61)\end{array}$ & $\begin{array}{l}-1.327 \\
(-1.04)\end{array}$ & & \\
\hline Structure-size & & & $\begin{array}{c}0.156^{*} \\
(1.89)\end{array}$ & $\begin{array}{l}-0.188 \\
(-0.64)\end{array}$ & & \\
\hline Finance-size (incl. bonds) & & & & & $\begin{array}{l}-0.170 \\
(-1.23)\end{array}$ & $\begin{array}{l}10.660 \\
(0.46)\end{array}$ \\
\hline Structure-size (incl. bonds) & & & & & $\begin{array}{l}0.170 \\
(1.30)\end{array}$ & $\begin{array}{l}-0.927 \\
(-0.20)\end{array}$ \\
\hline Financial openness & $\begin{array}{l}-0.049 \\
(-0.80)\end{array}$ & $\begin{array}{l}0.275 \\
(1.37)\end{array}$ & $\begin{array}{l}-0.064 \\
(-1.01)\end{array}$ & $\begin{array}{l}0.239 \\
(1.07)\end{array}$ & $\begin{array}{l}-0.003 \\
(-0.03)\end{array}$ & $\begin{array}{l}0.255 \\
(0.25)\end{array}$ \\
\hline Trade openness & $\begin{array}{c}0.305^{* * * *} \\
(2.99)\end{array}$ & $\begin{array}{c}0.892^{*} \\
(1.96)\end{array}$ & $\begin{array}{c}0.375 * * * \\
(4.22)\end{array}$ & $\begin{array}{c}0.980^{*} \\
(1.86)\end{array}$ & $\begin{array}{c}0.349 * * * \\
(3.05)\end{array}$ & $\begin{array}{l}2.834 \\
(0.48)\end{array}$ \\
\hline GDP per capita (US\$) & $\begin{array}{c}0.224 * * * \\
(3.35)\end{array}$ & $\begin{array}{l}0.509 \\
(0.82)\end{array}$ & $\begin{array}{c}0.189 * * * \\
(2.75)\end{array}$ & $\begin{array}{l}0.694 \\
(0.73)\end{array}$ & $\begin{array}{l}0.128 \\
(1.39)\end{array}$ & $\begin{array}{l}-6.884 \\
(-0.48)\end{array}$ \\
\hline Terms of trade volatility & $\begin{array}{l}1.819^{*} \\
(1.78)\end{array}$ & $\begin{array}{c}2.777 * \\
(1.71)\end{array}$ & $\begin{array}{c}2.187 * * \\
(2.12)\end{array}$ & $\begin{array}{l}4.293^{*} \\
(1.83)\end{array}$ & $\begin{array}{l}1.644 \\
(0.78)\end{array}$ & $\begin{array}{r}-16.300 \\
(-0.35)\end{array}$ \\
\hline Exchange rate volatility & $\begin{array}{l}-0.223 \\
(-0.25)\end{array}$ & $\begin{array}{l}-1.949 \\
(-1.44)\end{array}$ & $\begin{array}{l}-0.389 \\
(-0.41)\end{array}$ & $\begin{array}{l}-0.271 \\
(-0.14)\end{array}$ & $\begin{array}{l}-0.329 \\
(-0.17)\end{array}$ & $\begin{array}{c}-10.640 \\
(-0.71)\end{array}$ \\
\hline Government consumption & $\begin{array}{l}-0.003 \\
(-0.25)\end{array}$ & $\begin{array}{l}0.001 \\
(0.02)\end{array}$ & $\begin{array}{l}0.004 \\
(0.37)\end{array}$ & $\begin{array}{l}-0.026 \\
(-0.47)\end{array}$ & $\begin{array}{l}0.007 \\
(0.49)\end{array}$ & $\begin{array}{l}-0.771 \\
(-0.40)\end{array}$ \\
\hline Inflation & $\begin{array}{c}0.000^{* *} \\
(2.06)\end{array}$ & $\begin{array}{l}0.000 \\
(0.18)\end{array}$ & $\begin{array}{l}0.004 \\
(0.69)\end{array}$ & $\begin{array}{l}-0.017 \\
(-0.73)\end{array}$ & $\begin{array}{c}0.041 * * * \\
(3.22)\end{array}$ & $\begin{array}{l}0.362 \\
(0.52)\end{array}$ \\
\hline Polity & $\begin{array}{c}-0.032^{* * *} \\
(-3.10)\end{array}$ & $\begin{array}{c}-0.069 * * \\
(-2.14)\end{array}$ & $\begin{array}{c}-0.027 * * * \\
(-2.70)\end{array}$ & $\begin{array}{l}-0.037 \\
(-0.92)\end{array}$ & $\begin{array}{c}-0.031^{* *} \\
(-2.16)\end{array}$ & $\begin{array}{l}1.114 \\
(0.33)\end{array}$ \\
\hline Constant & $\begin{array}{c}-5.492 * * * \\
(-9.74)\end{array}$ & $\begin{array}{l}-8.536^{*} \\
(-1.90)\end{array}$ & $\begin{array}{c}-5.763 * * * \\
(-10.10)\end{array}$ & $\begin{array}{l}-8.378 \\
(-1.64)\end{array}$ & $\begin{array}{c}-6.044 * * * \\
(-6.83)\end{array}$ & $\begin{array}{l}1.598 \\
(0.06)\end{array}$ \\
\hline Number of observations & 178 & 178 & 170 & 170 & 84 & 84 \\
\hline R-squared & 0.238 & & 0.243 & & 0.245 & \\
\hline Number of country FE & & 52 & & 52 & & 34 \\
\hline Wu-Hausman test & $3.054^{* *}$ & & $4.115^{* *}$ & & 0.139 & \\
\hline Prob $>$ F & $0.00 * * *$ & $0.00^{* * *}$ & $0.00^{* * *}$ & $0.00 * * *$ & $0.00^{* * *}$ & $0.00 * * *$ \\
\hline Prob $>F_{u}$ & & 0.686 & & 0.623 & & 1.000 \\
\hline $\operatorname{Corr}\left(\mathrm{u}_{\mathrm{i}}, \mathrm{X}_{\mathrm{b}}\right)$ & & -0.913 & & -0.905 & & -0.984 \\
\hline
\end{tabular}

Note. Robust z-statistic in parenthesis. * significant at $10 \%$, ** significant at $5 \%$, *** significant at $1 \%$; IV means instrumental variable estimation (instruments: first lagged value of financial development and financial structure variables), IVFE is short of fixed effects instrumental estimation (instruments: first lagged value of financial development and financial structure variables), Wu-Hausman tests on exogeneity of instrumented variables, Prob $>$ F tests on joint significance of all explanatory variables except constant, Prob $>F_{u}$ tests on joint significance of all cross-country individual effects, Corr $\left(\mathrm{X}_{\mathrm{b}}, \mathrm{u}_{\mathrm{i}}\right)$ means correlation of predicted valued of the dependent variable $\left(\mathrm{X}_{\mathrm{b}}\right)$ and individual fixed effects $\left(\mathrm{u}_{\mathrm{i}}\right)$. 
Table 4 shows the regression outcomes of the business-cycle volatility of the investment growth model with three measures of financial development and structure. In contrast to the overall investment growth volatility estimates, the stock-based structure-size indicator has a significant positive effect on cyclical volatility of investment growth. The structure-activity and bonds included structure-size indicator are insignificant, similar to the findings reported in Tables 1-3. In line with our observations concerning the business-cycle volatility of output growth, the finance-activity and the stock-based finance-size indicators of financial development have a significant negative effect on cyclical volatility of investment growth, while the coefficient of the bonds included finance-size indicator is insignificant. Denizer et al. (2002) and Da Silva (2002) observe a similar effect, although their financial development indicator only incorporates financial intermediary development. The effects of trade openness are significant and positive in all three IV estimations. Terms of trade volatility, inflation and GDP per capita have a significant positive effect in two estimations, while the effect of the polity indicator is significantly negative in all three estimations.

\section{Conclusion and Implications}

The Capital Market Union initiative of the European Commission is aimed at stimulating the financial deepening and cross-border integration of domestic capital markets and would remove the obstacles that European businesses encounter in attracting funds on capital markets, complementing banks as a source of financing. In addition, the CMU would ensure greater diversification in the funding of the economy and reduce the cost of raising capital, particularly for small and medium-sized enterprises. It should enhance the flow of capital from investors to European investment projects, improving allocation of risk and capital across the EU (EC, 2015). Moreover, financial diversification and integrated European capital markets may improve risk sharing among households, contributing to lower volatility of income and consumption and supporting economic stability (Anderson et al., 2015). We do not find evidence that moving towards a more market-oriented financial system is beneficial to fostering stability.

This article investigates the impact of financial development and financial structure on macroeconomic volatility. We use a large panel dataset of 55 countries between 1975 and 2014, and distinguish between output and investment growth, as well as overall volatility and business cyclical volatility. We consider three different measures of financial development as well as of financial system structure. It appears that the financial structure does not have a significant effect on overall output volatility nor on its cyclical components. This indicates that moving towards a more market-oriented financial system may reduce output volatility. We find that an increase in the stock market size relative to that of the banking sector may contribute to business cycle volatility of investments, while an increase in stock market activity relative to that in the banking sector has no effect on the business-cycle volatility of investments. Financial structure is found to have no effect at all on overall investment growth volatility. These results suggest that moving towards are more market-oriented financial system may not be beneficial to promoting stability in investment growth. An increase in financial system activity may result in reduced overall volatility of output growth, while an increase in both the activity in - and the size of - the financial system may suppress business cycle volatility of output growth. In addition, we observe that an increase in either financial system activity or the size of the financial system may result in both reduced overall investment growth and business-cycle volatility of investments.

\section{Limitations and Future Research}

This study examines the effect of financial structure on macroeconomic volatility by focusing on the degree of market-orientation in a country's financial system. We define financial structure as the capital market size, including stock and bond markets, relative to the banking sector size. In reality, the financial system comprises other financial institutions and markets, such as venture capital and derivatives markets, pension funds, mutual funds, etc. These financial-system components may have different effects on macroeconomic volatility. Future research could focus on the different financial system components.

We investigate whether financial structure affects macroeconomic volatility. Future research could focus on how financial structure impacts macroeconomic volatility. Other structural characteristics of a country's financial system, such as asset concentration, competition and the degree of foreign ownership in the banking sector may also have impact on macroeconomic volatility. Non-linearity in the relationship between the structure of the financial system and macroeconomic volatility may also warrant attention.

We include bond market capitalisation as a measure of capital market development, but data on bond market capitalisation has only been available since 1990 and covers a relatively small number of countries. In addition, while value-traded serves as a measure for activity in the stock markets, no such activity measure is readily available for the bond markets. Further research could focus on the effect that bond markets have on 
macroeconomic volatility by not only considering the scale, but also the activity and efficiency of these markets.

Some studies argue that macroeconomic volatility may be path dependent, where previous volatility could impact current volatility. In order to control for this possibility, lagged volatility could be included in the regressions. Finally, our estimation takes account of potential endogeneity issues of financial development and financial structure by using their first lagged value as instruments. Other instruments, including creditors' and shareholders' protections measures and legal origin, may be more suitable but where not at hand. Alternative estimation procedures such as GMM using the Arellano-Bond conditions for a dynamic panel model could also be investigated.

The level of trust in financial markets or financial institutions is of importance for such a turn to the economies as the introduction of a CMU. People in the EU will at least indirectly have a say on such a policy upon its possible application. For a good review, see Drakos (2019) or Kallandranis et al. (2019). Such levels of trust could be included in the analyses.

\section{References}

Acemoglu, D., \& Zilibotti, F. (1997). Was Prometheus Unbound by Chance? Risk, Diversification, and Growth. Journal of Political Economy, 105(4), 709-751. https://doi.org/10.1086/262091

Aghion, P., Bacchetta, P., \& Banerjee, A. (2000). Capital markets and the instability of open economies. The Asian financial crisis: Causes, contagion and consequences, 167-194. https://doi.org/10.1017/cbo9780511559587.011

Alatrash, Y., Leff, D., Minten, T., Soupre, M., \& Van Schoot, D. (2014). Financial Development and Macroeconomic Volatility. mimeo, Barcelona Graduate School of Economics and Universitat Pompeu Fabra.

Allen, F., \& Gale, D. (1997). Financial Markets, Intermediaries, and Intertemporal Smoothing. Journal of Political Economy, 105(3), 523-546. https://doi.org/10.1086/262081

Allen, F., \& Gale, D. (2001). Comparative financial systems: A survey. Philadelphia, PA: Wharton School, University of Pennsylvania.

Anderson, N., Brooke, M., Hume, M., \& Kürtösiová, M. (2015). A European Capital Markets Union: Implications for growth and stability. Financial Stability Paper, (33).

Bacchetta, P., \& Caminal, R. (2000). Do capital market imperfections exacerbate output fluctuations? European Economic Review, 44(3), 449-468. https://doi.org/10.1016/S0014-2921(98)00083-X

Baum, C. F., Schäfer, D., \& Talavera, O. (2011). The impact of the financial system's structure on firms' financial constraints. Journal of International Money and Finance, 30(4), 678-691. https://doi.org/10.1016/j.jimonfin.2011.02.004

Beck, T., Lundberg, M., \& Majnoni, G. (2006). Financial intermediary development and growth volatility: Do intermediaries dampen or magnify shocks? Journal of International Money and Finance, 25(7), 1146-1167. https://doi.org/10.1016/j.jimonfin.2006.08.004

Bernanke, B. S., Gertler, M., \& Gilchrist, S. (1999). The financial accelerator in a quantitative business cycle $\begin{array}{lllll}\text { framework. Handbook of } & \text { Macroeconomics, }\end{array}$ https://doi.org/10.1016/S1574-0048(99)10034-X

Bijlsma, M., van Veldhuizen, S., \& Voght, B. (2015). Een wereld zonder banken? Marktfinanciering and bankfinanciering in perspectief (In Dutch; A world without banks? Market-based and banking-based financing in perspective). CPB Policy Brief, CPB Netherlands Bureau for Economic Policy Analysis, the Hague.

Boot, A. W. A., \& Thakor, A. V. (1997). Financial system architecture. Review of Financial Studies, 10(3), 693-733. https://doi.org/10.1093/rfs/10.3.693

Breen, R., \& García-Peñalosa, C. (1999). Income Inequality and Macroeconomic Volatility: An Empirical Investigation. European University Institute, Oxford.

Caballero, R. J., Hoshi, T., \& Kashyap, A. K. (2008). Zombie lending and depressed restructuring in Japan. The American Economic Review, 98(5), 1943-1977. https://doi.org/10.1257/aer.98.5.1943

Crouzet, N. (2014). Corporate debt structure and the macroeconomy. In Annual Meeting of the American Economic Association, Philadelphia, 3-5. 
Da Silva, G. F. (2002). The impact of financial system development on business cycles volatility: cross-country evidence. Journal of Macroeconomics, 24(2), 233-253. https://doi.org/10.1016/s0164-0704(02)00021-6

Dabla-Norris, E., \& Srivisal, N. (2013). Revisiting the link between finance and macroeconomic volatility. IMF Working Papers, 13(29), 1. https://doi.org/10.5089/9781475543988.001

De Fiore, F., \& Uhlig, H. (2015). Corporate debt structure and the financial crisis. Journal of Money, credit and Banking, 47(8), 1571-1598. https://doi.org/10.1111/jmcb.12284

Denizer, C. A., Iyigun, M. F., \& Owen, A. (2002). Finance and Macroeconomic Volatility. Contributions in Macroeconomics, 2(1). https://doi.org/10.2202/1534-6005.1048

Drakos, K., Kallandranis, C., \& Karidis, S. (2019). Determinants of trust in institutions: Survey based evidence from the European Union, Journal of Common Market Studies, 57(6), 1228-1246, https://doi.org/10.1111/jcms.12884

Easterly, W., Roumeen, I., \& Stiglitz, J. (2001). Shaken and stirred: Explaining growth volatility. Annual World Bank Conference on Development Economics.

European Commission. (2015). Green Paper - Building a Capital Market Union, 27. Retrieved from http://eur-lex.europa.eu/legal-content/EN/TXT/PDF/?uri=COM:2015:63:FIN\&from=EN

Fecht, F. (2004). On the Stability of Different Financial Systems. Journal of the European Economic Association, 2(6), 969-1014. https://doi.org/10.1162/1542476042813832

Gambacorta, L., Yang, J., \& Tsatsaronis, K. (2014). Financial Structure and Growth. BIS Quarterly Review, 17(4), 1-37.

Gertler, M., \& Bernanke, B. (1995). Inside the black box: The credit channel of monetary policy transmission, The Journal of Economic Perspectives, 9(4), 27-48. https://doi.org/10.3386/w5146

Jenkins, P. (2015). What has delayed Europe's bank recovery? Financial Times (online), November 9. Retrieved from https://www.ft.com/content/9e6f450c-86d8-11e5-90de-f44762bf9896

Kallandranis, C. (2019). The interaction of citizen's trust between European Commission and National Politics during the crisis, Journal of Risk Governance and Control: Financial Markets \& Institutions, 9(4), 8-19. https://doi.org/10.22495/rgcv9i4p1

Kiyotaki, N., \& Moore, J. (1997). Credit Cycles. Journal of Political Economy, 105(2), 211-248. https://doi.org/10.1086/262072

Klomp, J., \& De Haan, J. (2009) Political institutions and economic volatility, European Journal of Political Economy, 25, 311-326. https://doi.org/10.1016/j.ejpoleco.2009.02.006

Langfield, S., \& Pagano, M. (2016). Bank bias in Europe: effects on systemic risk and growth. Economic Policy, 31 (85), 51-106. https://doi.org/10.1093/epolic/eiv019

Levine, R. (2005). Finance and Growth: Theory and Evidence. Handbook of Economic Growth, 1 (Suppl. Part A), 865-934. https://doi.org/10.1016/S1574-0684(05)01012-9

Levine, R., Lin, C., \& Xie, W. (2016). Spare tire? Stock markets, banking crises, and economic recoveries. Journal of Financial Economics, 120(1), 81-101. https://doi.org/10.1016/j.jfineco.2015.05.009

Mallick, D. (2014). Financial Development, Shocks, and Growth Volatility. Macroeconomic Dynamics, 18(3), 651-688. https://doi.org/10.1017/S1365100512000569

Quadrini, V. (2011). Financial Frictions in Macroeconomic Fluctuations. Economic Quarterly, 97(3), 209-254.

Raddatz, C. (2006). Liquidity needs and vulnerability to financial underdevelopment. Journal of Financial Economics, 80(3), 677-722. https://doi.org/10.1016/j.jfineco.2005.03.012

Ramey, G., \& Ramey, V. A. (1995). Cross Country Evidence of the Link BetweenVolatility and Growth. The American Economic Review. https://doi.org/10.3386/w4959

Sahay, R., Cihak, M., N'Diaye, P., Barajas, A., Ayala Pena, D., Bi, R., \& Yousefi, R. (2015). Rethinking Financial Deepening: Stability and Growth in Emerging Markets. Staff Discussion Notes, 15(8), 1. https://doi.org/10.5089/9781498312615.006

Tharavanij, P. (2007). Capital market and business cycle volatility. Monash University Economics Discussion Paper.

Wei, F., \& Kong, Y. (2016). Financial Development, Financial Structure, and Macroeconomic Volatility: 
Evidence from China. Sustainability, 8, 1-20. https://doi.org/10.3390/su8111116

World Bank. (2013). Rethinking the Role of the State in Finance. Global Financial Development Report.

Yeh, C. C., Huang, H. C. (River), \& Lin, P. C. (2013). Financial structure on growth and volatility. Economic Modelling, 35, 391-400. https://doi.org/10.1016/j.econmod.2013.07.034

Zingales, L. (2001). Financial systems, industrial structure and growth. Oxford Review of Economic Policy, 17(4), 467-482. https://doi.org/10.1093/oxrep/17.4.467

\section{Notes}

Note 1. EU-4 shows the average annual values of Europe's four largest economies: Germany, United Kingdom, Italy and France.

Note 2. 1975-1979, 1980-1984,1985-1989, 1990-1994, 1995-1999, 2000-2004, 2005-2009, 2010-2014.

Note 3. Value traded is the ratio of stock market total value traded to GDP. Bank credit is the ratio of private credit by deposit money banks to GDP.

Note 4. Private credit is the ratio of private credit by deposit money banks and other financial institutions to GDP and is used in order to capture not only the activity of banks but also that of other non-depository financial intermediaries.

Note 5. Both the financial structure and financial development indicators are first calculated on an annual basis. Next we calculate the five-year average of each indicator to use in the regressions.

Note 6. We endeavoured to replicate the work of Tharavanij (2007), using an updated database. Our outcomes deviated from those of Tharavanij (2007), possibly due to changes in the data

Note 7. The F-test statistic on the fixed effects in the IVFE estimations of all three models is insignificant, thus the null hypothesis of zero country-specific effects cannot be rejected. Hence we consider IV estimations as the appropriate ones.

Note 8. The fixed effect estimations outcomes (IVFE) show that the structure indicators lose their significance after controlling for country-specific effects, probably because fixed effects picks up the cross country effect and the structure changes relatively little over time. The financial development lose their significance. Terms of trade volatility remains significant in two out of three IVFE estimations while all other explanatory variables have an insignificant coefficient. Weighted average estimations do not change our findings.

\section{Appendix. Descriptives of the dataset}

Table A.1. List of countries used in the dataset

\begin{tabular}{llll}
\hline Australia & Côte d'Ivoire & Italy & Portugal \\
Austria & Denmark & Japan & Russian Federation \\
Belgium & Ecuador & Latvia & Saudi Arabia \\
Bolivia & Finland & Luxembourg & Singapore \\
Brazil & France & Malaysia & South Africa \\
Bulgaria & Georgia & Mexico & Spain \\
Canada & Germany & Morocco & Sweden \\
Chile & Ghana & Netherlands & Switzerland \\
China & Greece & New Zealand & Trinidad and Tobago \\
Colombia & Hungary & Nigeria & United Kingdom \\
Costa Rica & Iceland & Norway & United States \\
Croatia & Iran, Islamic Rep. & Pakistan & Uruguay \\
Cyprus & Ireland & Philippines & Venezuela \\
Czech Republic & Israel & Poland & \\
\hline
\end{tabular}


Table A.2. Variable names, description and sources

\begin{tabular}{|c|c|c|}
\hline Variable & Description & Source \\
\hline \multicolumn{3}{|l|}{ Dependent variables } \\
\hline Output growth volatility & Ln (Standard deviation of real GDP per capita growth) & World Development Indicators, World Bank \\
\hline $\begin{array}{l}\text { Output growth business } \\
\text { cycle volatility }\end{array}$ & $\begin{array}{l}\text { Ln (Standard deviation of the business cycle component } \\
\text { of real GDP per capita growth) }\end{array}$ & World Development Indicators, World Bank \\
\hline Investment volatility & $\begin{array}{l}\text { Ln (Standard deviation of gross fixed capital formation } \\
\text { growth) }\end{array}$ & World Development Indicators, World Bank \\
\hline $\begin{array}{l}\text { Investment growth business } \\
\text { cycle volatility }\end{array}$ & $\begin{array}{l}\text { Ln (Standard deviation of the business cycle component } \\
\text { of gross fixed capital formation growth) }\end{array}$ & World Development Indicators, World Bank \\
\hline \multicolumn{3}{|l|}{ Explanatory variables } \\
\hline Structure-activity & $\begin{array}{l}\text { Ln(stock market total value traded / private credit by } \\
\text { deposit money banks) }\end{array}$ & $\begin{array}{l}\text { Financial Structure Database, World Bank } \\
\text { (June 2016) }\end{array}$ \\
\hline Structure-size & $\begin{array}{l}\text { Ln (stock market capitalisation / private credit by } \\
\text { deposit money banks) }\end{array}$ & $\begin{array}{l}\text { Financial Structure Database, World Bank } \\
\text { (June 2016) }\end{array}$ \\
\hline $\begin{array}{l}\text { Structure-size } \\
\text { (including bonds) }\end{array}$ & $\begin{array}{l}\text { Ln ((stock market capitalisation + private bond market } \\
\text { capitalisation) / private credit by deposit money banks) }\end{array}$ & $\begin{array}{l}\text { Financial Structure Database, World Bank } \\
\text { (June 2016) }\end{array}$ \\
\hline Finance-activity & $\begin{array}{l}\text { Ln (private credit by deposit money banks and other } \\
\text { financial institutions }+ \text { stock market total value traded) }\end{array}$ & $\begin{array}{l}\text { Financial Structure Database, World Bank } \\
\text { (June 2016) }\end{array}$ \\
\hline Finance-size & $\begin{array}{l}\text { Ln (private credit by deposit money banks and other } \\
\text { financial institutions }+ \text { stock market capitalisation) }\end{array}$ & $\begin{array}{l}\text { Financial Structure Database, World Bank } \\
\text { (June 2016) }\end{array}$ \\
\hline $\begin{array}{l}\text { Finance-size } \\
\text { (including bonds) }\end{array}$ & $\begin{array}{l}\text { Ln (private credit by deposit money banks and other } \\
\text { financial institutions }+ \text { stock market capitalisation }+ \\
\text { private bond market capitalisation) }\end{array}$ & $\begin{array}{l}\text { Financial Structure Database, World Bank } \\
\text { (June 2016) }\end{array}$ \\
\hline Financial openness & Ln (FDI inflows + FDI outflows)/ GDP & World Development Indicators, World Bank \\
\hline Trade openness & Ln (Imports + Exports)/ GDP & World Development Indicators, World Bank \\
\hline GDP per capita & Ln (real GDP per capita in US\$ in 2010 prices) & World Development Indicators, World Bank \\
\hline Terms of trade volatility & $\begin{array}{l}\text { Standard deviation of changes in net barter terms of } \\
\text { trade index }\end{array}$ & World Development Indicators, World Bank \\
\hline Exchange rate volatility & $\begin{array}{l}\text { Standard deviation of changes in the real effective } \\
\text { exchange rate (based on CPI) }\end{array}$ & $\begin{array}{l}\text { Own calculations } \\
\text { World Development Indicators, World Bank }\end{array}$ \\
\hline Government consumption & Government final consumption expenditure / GDP & World Development Indicators, World Bank \\
\hline Inflation & Annual change $(\%)$ consumer prices & World Development Indicators, World Bank \\
\hline Polity index & $\begin{array}{l}\text { Index ranging between }-10 \text { (autocratic regimes) and }+10 \\
\text { (democratic regimes). }\end{array}$ & Polity IV \\
\hline
\end{tabular}

Table A.3. Key descriptive statistics of the model variables

\begin{tabular}{|c|c|c|c|c|c|c|}
\hline Variables & Abbreviations & Obs & Mean & Std. Dev & Min & Max \\
\hline GDP per capita growth volatility & Gvol & 417 & 0.027 & 0.035 & 0.003 & 0.588 \\
\hline GDP per capita business cycle volatility & Gbcvol & 417 & 0.023 & 0.018 & 0.002 & 0.154 \\
\hline Investment growth volatility & Ivol & 377 & 0.113 & 0.122 & 0.004 & 1.746 \\
\hline Investment growth business cycle volatility & Ibcvol & 377 & 0.023 & 0.018 & 0.002 & 0.154 \\
\hline Structure-activity & FSactivity & 327 & 0.375 & 0.642 & 0.0004 & 6.2670 \\
\hline Structure-size & FSsize & 315 & 0.866 & 0.685 & 0.024 & 3.368 \\
\hline Structure-size (incl. bonds) & FSsizeB & 144 & 1.413 & 0.883 & 0.113 & 4.623 \\
\hline Finance-activity & FAactivity & 327 & 97.019 & 76.060 & 7.41 & 434.72 \\
\hline Finance-size & FAsize & 315 & 123.541 & 83.046 & 10.064 & 375.618 \\
\hline Finance-size (incl. bonds) & FAsizeB & 144 & 194.749 & 100.0273 & 26.066 & 433.612 \\
\hline Financial openness & Fopen & 364 & 6.323 & 12.748 & 0.101 & 136.761 \\
\hline Trade openness & Topen & 414 & 75.016 & 56.568 & 9.502 & 410.247 \\
\hline GDP per capita & GDPcap & 417 & 21344.44 & 19449.28 & 289.738 & 104878.5 \\
\hline Terms of trade volatility & SD-DTOT & 247 & 0.067 & 0.066 & 0.004 & 0.402 \\
\hline Exchange rate volatility & SD-DREER & 416 & 21,343 & 19,473 & 289.7 & 104,879 \\
\hline Government consumption & Gov & 415 & 16.96 & 4.911 & 7.029 & 38.68 \\
\hline Inflation & Inflation & 409 & 24.662 & 149.102 & -1.174 & 2414.346 \\
\hline Polity index & Polity & 412 & 5.848 & 6.210 & -10 & 10 \\
\hline
\end{tabular}


Table A.4. Correlation matrix of the model variables

\begin{tabular}{|c|c|c|c|c|c|c|c|c|c|c|}
\hline & Gvol & Gbcvol & Ivol & Ibcvol & FSactivity & FSsize & FS-sizeB & FAactivity & FA-size & FA-sizeB \\
\hline Gvol & 1.00 & & & & & & & & & \\
\hline Gbcvol & 0.568 & 1.00 & & & & & & & & \\
\hline Ivol & 0.299 & 0.479 & 1.00 & & & & & & & \\
\hline Ibcvol & 0.519 & 0.999 & 0.479 & 1.00 & & & & & & \\
\hline FSactivity & -0.062 & -0.076 & -0.134 & -0.102 & 1.00 & & & & & \\
\hline FSsize & -0.006 & 0.012 & -0.002 & 0.026 & 0.477 & 1.00 & & & & \\
\hline FSsizeB & -0.064 & 0.005 & -0.028 & 0.006 & 0.621 & 0.862 & 1.00 & & & \\
\hline FAactivity & -0.120 & -0.158 & -0.198 & -0.178 & 0.602 & 0.197 & 0.231 & 1.00 & & \\
\hline FAsize & -0.083 & -0.119 & -0.180 & -0.139 & 0.389 & 0.388 & 0.355 & 0.885 & 1.00 & \\
\hline \multirow[t]{2}{*}{ FAsizeB } & 0.051 & 0.043 & -0.024 & 0.043 & 0.424 & 0.322 & 0.391 & 0.884 & 0.959 & 1.00 \\
\hline & Gvol & Gbcvol & Ivol & Ibcvol & FAactivity & FSactivity & FAsize & FSsize & FA-sizeB & FS-sizeB \\
\hline Fopen & 0.020 & 0.058 & -0.015 & 0.057 & 0.036 & 0.099 & -0.006 & 0.238 & 0.324 & 0.236 \\
\hline Topen & 0.028 & 0.077 & 0.041 & 0.095 & -0.007 & 0.189 & 0.054 & 0.138 & 0.316 & 0.219 \\
\hline GDPcap & -0.127 & -0.254 & -0.24 & -0.253 & 0.212 & 0.018 & 0.066 & 0.577 & 0.571 & 0.515 \\
\hline DToT & 0.278 & 0.319 & 0.395 & 0.363 & -0.023 & 0.110 & 0.073 & -0.345 & -0.353 & -0.166 \\
\hline Dreer & 0.145 & 0.314 & 0.290 & 0.297 & -0.084 & 0.061 & 0.009 & -0.193 & -0.181 & -0.074 \\
\hline Gov & -0.088 & -0.200 & -0.196 & -0.2200 & 0.010 & -0.174 & -0.073 & -0.119 & 0.044 & 0.009 \\
\hline Inflation & 0.028 & 0.014 & 0.141 & 0.014 & -0.057 & -0.080 & -0.121 & -0.120 & -0.122 & -0.440 \\
\hline \multirow[t]{2}{*}{ Polity } & -0.184 & -0.392 & -0.129 & -0.425 & -0.092 & -0.116 & 0.083 & 0.176 & 0.187 & 0.081 \\
\hline & Fopen & Topen & GDPcap & DToT & Dreer & Gov & Inflation & Polity & & \\
\hline Fopen & 1.00 & & & & & & & & & \\
\hline Topen & 0.549 & 1.00 & & & & & & & & \\
\hline GDPcap & 0.422 & 0.313 & 1.00 & & & & & & & \\
\hline DToT & -0.238 & -0.277 & -0.353 & 1.00 & & & & & & \\
\hline Dreer & -0.148 & -0.228 & -0.314 & 0.507 & 1.00 & & & & & \\
\hline Gov & 0.072 & -0.022 & 0.380 & -0.404 & -0.305 & 1.00 & & & & \\
\hline Inflation & -0.060 & -0.084 & -0.116 & 0.110 & 0.341 & -0.072 & 1.00 & & & \\
\hline Polity & 0.116 & 0.008 & 0.461 & -0.338 & -0.267 & 0.238 & 0.003 & 1.00 & & \\
\hline
\end{tabular}

\section{Copyrights}

Copyright for this article is retained by the author(s), with first publication rights granted to the journal.

This is an open-access article distributed under the terms and conditions of the Creative Commons Attribution license (http://creativecommons.org/licenses/by/4.0/). 